\title{
DAMPAK PEMBELAJARAN DARING TERHADAP PENGEMBANGAN KEPRIBADIAN PESERTA DIDIK
}

\author{
Sri Rahayu \\ 1910128220017@mhs.ulm.ac.id \\ Program Studi Pendidikan IPS Fakultas Keguruan dan Ilmu Pendidikan Universitas \\ Lambung Mangkurat.
}

\begin{abstract}
ABSTRAK
Pembelajaran daring membawa dampak terhadap perkembangan peserta didik mulai dari semangat belajar, nilai bahkan kepribadian peserta didik. Pembelajaran daring yang di lakukan selama setahun terakhir ini memiliki dampak pada sikap dan kepribadian peserta didik.. Pada pembelajaran daring ini dapat membuat mood dan suasana hati peserta didik berubah rubah karena fakot jenuh dan lelah. Hal ini karena suasana belajar yang tidak mendukung dari lingkungan belajar peserta didik. Pembelajaran yang dilakukan selama daring menyebabkan peserta didik tidak sering bertemu orang banyak dan menyebabkan peserta didik kurang bersosialisasi dengan teman-teman di sekolahnya secara langsung. Pembelajaran ini tidak hanya dapat membentuk kepribadian yang introvert pada peserta didik, namun juga dapat menyebabkan penurunan semanngat belajar peserta didik. Dalam penulisan ini berupaya untuk mengetahui bagaimana dampak dari adanya pembelajaran daring pada perkembangan kepribadian pesera didik. Aspek yang akan di capai dalam penulisan ini adalah, bagaimana proses pembelajaran yang efektif dan pengunaan metode pembelajaran semasa daring agar peserta didik tetap merasa senang dan tidak jenuh. Penelitian ini dilakukan dari berberapa studi kasus dari referensi berberapa jurnal dan kajian ilmiah.
\end{abstract}

Keyword : Pembelajaran daring, kepribadian peserta didik, pembelajaran efektif. PENDAHULUAN

Pembelajaran merupakan suatu daring system pendidikan yang dilaksanakan secara menyeluruh di pendidikan di Indonesia setelah adanya suatu virus yang mengharuskan masyarakat tetap berada di rumah dan mengurangi insensitas untuk bertemu orang banyak. 
System pembelajaran yang berbasis dengan memanfaatkan teknologi dan internet. Pembelajaranya pun di lakukan dengan menggunakan media seperti aplikasi-aplikasi serupa Zoom, Geogle meet, Geogle Clasroom dan e-learning. Pembelajaran daring ini di lakukan dari jenjang Pendidikan TK sampai dengan perkuliahan.

Menurut Nur'azizah, dkk (2021) di jelaskan pembelajaran jarak jauh atau yang di kenal dengan daring memiliki suatu dampak yang berhubungan dengan Kesehatan mental peserta didik. Hal tersebut dapat terlihat dari berberapa perubahan yang terdapat dari peserta didik akibat pembelajaran daring ini yaitu. Peserta didik kurang dapat memahami secara jelas materi yang di sampaikan oleh guru yang membuat dirinya harus berpikir sendiri, hal ini juga berhubungan dengan kurikulum 2013 yang menekankan pembelajaran aktif kepada peserta didik, namun peserta didik kurang memahami materi yang di berikan. Hal ini menyebabkan berberapa pengaruh terhadap Kesehatan mental peserta didi, seperti peserta didik akan lebih sering cemas dan kebingungan ketika peserta didik di tunjuk oleh guru untuk menjelaskan dan menajwab pertanyaan karena peserta didik kurang memahami penjelaskan yang di berikan oleh guru, selain itu akibat pembelajaran daring ini tugas yang di berikan setiap mata pelajaran yang di berikan secara bersamaan dan dengan waktu pengumpulan yang berdekatan akan membuat peserta didik akan mudah menjadi frustasi.

Menurut rusman dkk dalam Subiyakto (2019) mengatakan bahwa media pembelajaran merupakan suatu teknologi yang di guunakan dalam proses pembelajaran berbentuk saaaarana fisik dan dapat di komuniasikan melalui teknologi maupun secara tradisional, media pembelajaran ini merupakan komponen penting di dalam pembelajaran yang dapat membuat peserta didik mengolahm mengetahui dan mencari informasi berdasarkan pengetahuan, sikap dan keterampilan peserta didik. Media pembelajaran di gunakan untuk meningkatkan pembelajaran agar menjadi lebih efektif

Menurut Eysenck dalam jurnal (Ulya,2017) kepribadian ekstrovet merupakan suatu kepribadian yanh suka melakukan kegiatan yang memerlukan tenaga, suka bersosialisasi dan seorang yang memilki kepribadian ini memilki jiwa bebas dan sulit untur menaati perauran. Hal ini juga sesuai dengan pendapat Artur dia mengatakan bahwa kepribadian ekstrovet merupakan seorang yang mudah mengekspresikan dirinya di dalam lingkunganya. Menurut (Musrifah, dkk) introvert merupakan suatu kepribadian atau sebuah sifat yang berorientasi 
pada subjektif. Seorang yang introvert meimiliki sebuah perasaan dan pemahaman yang berfokus pada diri mereka sendiri, orang yang memiliki sifat ini adakan menerima orang dari luar dengan selektif an dengan pandangan subjektif mereka.

\section{METODE}

Pada penulisan ini menggunakan studi literatur dengan mengumpulkan berberapa data dan informasi dari berbagai referensi yang relevan dengan materi yang akan di kaji mengenai dampak pembelajaran terhadap pengembangan kepribadian peserta didik.

\section{PEMBAHASAN}

Menurut Abdusshomad dalam Suriadi, dkk (2021) pembelajaran daring merupakan suatu proses pembelajaran yang di lakukan dengan memanfaatkan berbagai situs dan perangkat keras seperti laptop. Handphone, dan computer dalam sebuah situs yang relevan dengan sekolah berupa Zoom, Geogle meet, Geogle Clasroom bahkan e-learning. Pembaharuan dalam pembelajaran daring ini menimbulkan permasalahan baru dalam Pendidikan. Proses pembelajaran yang terjadi menjadi kurang efektif dari pada pembelajaran normal pada umumnya.

Menurut Robandi dan Mudjiran dalam Suriadi, dkk (2021) menjelaskan bahwa pembelajaran daring ini akan membuat peserta didik menjadi bingung, strees, kurang kreatif, kurangnya minat untuk melukakan sesuatu yang di akibatkan kurangnya pengawasan guru sebagai guru pembimbing peserta didik. Dengan pemelajaran daring,peserta didik di tuntut untuk mandiri dalam segala hal termasuk belajar dan memahami materi. Dengan adanya pembelajaran daring ini juga peserta didik lebih banyak menggunakan gadget dalam segala kegiatannya.

Pada perkembangan zaman sekarang, perlunya pengetahuan mengenai teknologi memang sangat penting, namun dalam penggunaan teknologi untuk peserta didik di usia7-10 tahun memang harus di perhatikan. Rata-rata para peserta didik jenjang SD sekarang ini sudah dapat mengoperasikan smartphone mereka dengan lancer, hal ini di dukung juga oleh pengaruh pembelajaran daring yang terjadi pada masa pandemic sekarang ini. Namun semakin lama nya proses pembelajaran daring menyebabkan peserta didik ketagihan untuk menggunakan smartphonenya walaupun bukan untuk mengerjakan tugas ataupun melakukan segala sesuatu yang berhubungan dengan tugas. 
Satu diantara dampak akibat dari pembelajaran daring kepada peserta didik berakibat pada kepriadian peserta didik yang tercipta selama proses belajar daring. Kepribadian yang di maksud berupa kepribadian ekstrovet dan introvert yang aka nada dalam diri peserta didik. Pada dasarnya, kepribadian ekstrovet dan introvert merupakan kepribadian yang yang dimilikisetiap orang, dalam Pendidikan guru harus menyesuaikan diri dan metode pembelajaran yang esuai dengan peserta didik apalagi pada masa pembelajaran daring sekarang, guru akan sulit mengidentifikasi secara langsung kepribadian peserta didik.

Menurut Eysenck dalam jurnal Ulya, (2017) kepribadian Ekxtrovert dan iIntrovert dipengaruhi oleh berberapa hal yaitu

1) Aktivitas, peserta didik yang memilki kepribadian ekstrovet akan memiliki aktivitas yang memerlukan aksi dan bersifat bebas karena pada kepribadian ini seorang yang ekstroovet orang yang lebih suka bersosialisasi dengan orang lain sehingga dalam pembelajaran kepribadian ini tidak telalu menyukai aktivitas yang hanya mendengarkan dan berdiam diri saja. Namun untuk kepribadian Introvet, peserta didik yang memiliki kepribadian ini merupakan seorang yang suka dengan tipe pembelajaran atau aktivitas yang hanya melibatkan pikiran dari pada Tindakan, paa kepribadian ini, peserta didik lebih suka menyendiri dan susah di ajak untuk bersosialisasi

2) Kemampua berpikir, kemampuan berpikir dua kepribadian ini tidak jelas berbeda namun yang Nampak berbeda adalah bagaimana mereka mengolah dan memfokuskan pemikirannya dalam menerima pembelajaran dan pengimplemntasikannya

3) Mengambil resiko atau bertindak, pada banyak pandangan mengatakan bahwa kepribadian ekstrovet dalam pengamboln Tindakan selalu bertindak gegabah dan seorang yang memiliki kepribadian introvert akan memikirkan secara rinci dan detail terlebih dahulu.

Dari penjelasan mengenai kepribadian introvert dan ekstrovet ini dapat di katakana bahwa dalam pembelajaran daring juga dapat mempengaruhi kepribadian peserta didik. Misalkan peserta didik yang memiliki kepribadian ekstrovet yang lebih suka pembelajaran yang mengharuskan beraktivitas dan bertemu orang banyak namun sekarang dia malah harus belajar melalui smartphone atau laptop melalui ditigal yang membuat dia tidak bisa mengespresikan dirinya sesuai dengan kepribadianya, sehingga terlihat peserta didik tersebut 
akan lebih banyak diam bahkan kurang merespon apa yang di berikan oleh gurunya. Maka dapat di katakana bahwa pembelajaran daring ini juga dapat memicu adanya perkembangan kepribadian introvert pada peserta didik karena terbatasnya ruang peserta didik dalam mengembangan kepribadiannya.

Pada proses pembelajaran memiliki suatu karakteristik yang di jelaskan oleh Putro, dkkm (2019) karakteristik tersebut ialahah suatu standar kmpetensi lulusan dan standar isi. Dalam standar kompetensi lulusan (SKL) berisikan suatu konsep dalam pembelajaran yang harus di capai. Dan standar isi (SI) berisikan kegiatan pembelajaran yang mencakup pengembangan ranah kognitif, afektif dan psikomotorik peserta didik. Ketiga ranah tersebut berhubungan dengan perkembangan kepribadian ( proses psikologis), yaitu dimana pembelajaran di lakukan melalui sebuah aktivitas yang mebuat peserta didik dapat mengembangkan kepribadianya dalam memperoleh pengetahuan. Kemudian juga, dalam kognitif dan afektif di pengaruhi oleh kepribadian peserta didik bagaimana peserta didik tersebut mengamati, menanya dan menalar pengetahuan dan keterampilannya. Dengan kepribadian ( ekstrovet dan introvert) peserta didik dapat mengelola pengetahuan dan dapat mengembangkan keterampilanya dan dapat bersikap sesuai dengan yang dia rasakan dan alami.

Dalam pembelajaran daring menggunakan kurikulum 2013 yang dimana menurut (Syaharuddin \& Mutiani, 2020) dalam pembelajaran kurikulum 2013 berorientasi untuk menghasilkan peerta didik yang kreatif, produktif, inovativ dan memiliki sikap, keterampilan dan pengetahuan yang dapat di integrasikan dalam kehidupan sehari-hari pesera didik. Namun pembelajaran yang terlihat pada masa pembelajaran sekarang, namun menurut (Syaharuddin, 2020) mengatakan bahwa pembelajaran daring ini pada awalnya merupakan system yang efektif untuk solusi dari adanya pandemic sekarang yang dimana harus mengurangi insensitas untuk keluar rumah. Pada saat sekarang, peserta didik kurang merespon dan kurang aktif dalam pembelajaran. Apalagi Ketika guru menjelaskan menggunakan metode ceraamah peserta didik akan lebih banyak tidak merespon bahwa tidak mendengarkan. Dikatakan juga bahwa dalam mengajar dalam system sekarang ini, pendidik harus bisa dapat menjaga "mood" peserta didik agar peserta didik dapat aktif dalam pembelajaran. 
Pembelajaran yang efektif pembelajaran menurut Setyosari (2017) merupakan suatu pembelajaran yang berhubungan dengan guru dalam menciptakan preoses pembelajaran yang dapat menghasilkan pengalaman belajar pada peserta didik. Untuk mencapai pembelajaran yang efektif, yang pertama di lakukan adalah seorang guru tersebut juga harus efektif. Dalam kategori guru efektif sebagai berikut yaitu guru menggunakan waktu pembelajaran secara maksimal yang berarti di sini guru tidak melakukan korupsi waktu jam pelajaran, guru menyiapkan bahan materi pembelajaran, guru memprogramkan pembelajaran nya, guru enciptakan suasana belajar yang dapat menciptakan pengalaman belajar bagi peserta didik dan guru mencapai tujuan pembelajaran. Dalam pembelajaran dengan system daring ini agar kepribadian peseta didik dapat di kembangkan maka di perlukanya peran guru yang efektif dan aktif agar tercipta pembelajaran yang efektif.

Model pembelajaran yang dapat di gunakan pada masa daring dapat di gunakan dengan metode "Blended Learning Models" menurut (Syaharudin, 2020) model pembelajaran ini mengabungkan anatara pembelajaran dengan system tatap muka dengan system daring (berbasis digital) karena pada masa pembelajaran daring erat kaitannya dengan teknologi. Model ini pada prakteknya di lakukan dengan pemberian tugas, tatap umuka dan live learning. Pembelajaran ini tentuna berbeda dengan system e-learning yang keseluruhanya memanfaatkan teknologi, dengan model pembelajaran ini maka guru akan dapat mengawasi peserta didik secara tidak langsung mealui proses ttap muka, guru juga dapat mengembangkan metode belajarnya yang tidak hanya berbasis ceramah saja, karena jika guru tetap menggunakan metode ceramah peserta didik akan cepat bosan dan tidak mengerti. Selain itu untuk dapat mengembatkan keterampilan sesuai dengan kepribadian peserta didik, seorang guru juga dapat memberikan tugas yang sesuai dengan kepibadian peserta didik tersebut namun masih dalam konteks materi pembelajaran. Misal mata pelajaran sosiologi, guru dapat meminta peserta didik membuat tugas mengenai mobilitas sosial pada peserta didik dan untuk format tugasnya guru dapat memberikan tpilihan berupa video ataupun format essay, biasanya peserta didik yang memiliki kepribadian ekstrovet dia akan memilih format tugas video karena dalam video dia akan dapat mengembangkan diri dan ekspresinya sedangkan banyak diantara orang memliki kepribadian introvert ini akan. 


\section{SIMPULAN}

Pengaruh adanya Pandemi pada masa sekarang membawa dampak terhadap banyak hal terutama pada Pendidikan. Melalui peraturan pemerintah maka hingga saat ini system Pendidikan di Indonesia mengalami perubahan. Perubahan tersebut seperti perubahan pada model pembelajaran, system pembelajaran, metode pembelajaran dan bahkan cara guru mengajar. Pembelajaran tersebut berupa pembelajaran daring. Sudah hamper memasuki satu tahun system pembelajaran daring di Indonesia namun perkembangannya tidak membawa dampak yang berarti, yang maknanya ada dampak negative yang terdapat dari pembelajaran daring ini, satu diantaranya adalah terhadap perkembangan kepribadian perserta didik. Kepribadian peserta didik terdapat dalam dua hal yaitu ekstrovet dan intovet. Dalam proses pembelajaran yang tidak efektif dapat menyebabkan kepribadian tersebut dalam peserta didik. Tentunya pada pandemic sekarang banyak sekali proses pembelajaran yang tidak efektif yang dapat mempengaruhi kepribadian peserta didik tersebut, misalnya peserta didik yang memiliki kepribadian ekstrovet dalam pembeljaran daring sekarang akan lebih banyak diam dan menyebabkan dirinya mempunyai kepribadian introvert. Untuk mengatasi permasalahan tersebut, dalam penulisan ini menyimpulkan bahwa pembelajaran yan efektif semasa daring dapat di lakukan dengan metode pembelajaran " Blended Learning Models" yaitu system pembelajaran tatap muka yang di kombinasikan dengan system daring yang memanfaatkan teknologi, dalam pembelajaran ini guru dapat berperan aktif mengawasi secara virtual tingkah laku dan perkembangan peserta didik. 


\section{DAFTAR PUSTAKA}

Musrifah, M., Yuline, Y., \& Astuti, I. ANALISIS PESERTA DIDIK BERKEPRIBADIAN INTROVERT KELAS $X$ JURUSAN PEMASARAN SMK NEGERI 3 PONTIANAK. Jurnal Pendidikan dan Pembelajaran Khatulistiwa, 8(7), 603-614.

Nur’Azizah, L. Y., Lestari, B. M., \& Magdalena, I. (2021). Dampak Mental bagi Siswa Sekolah Dasar Negeri Buaran Mangga II Akibat Pembelajaran Jarak Jauh. Cerdika: Jurnal Ilmiah Indonesia, 1(2), 121-129.

Putro, H. P. N., Wahyu, W., Subiyakto, B., Arisanty, D., \& Anis, M. (2019). Peningkatan Pemahaman Guru Mengenai Pembelajaran Saintifik Pada Kurikulum 2013 Bagi Guru MTs Provinsi Kalimantan Selatan.

Setyosari, P. (2017). Menciptakan pembelajaran yang efektif dan berkualitas. Jinotep (jurnal inovasi dan teknologi pembelajaran): kajian dan riset dalam teknologi pembelajaran, 1(1), 20-30.

Subiyakto, B. (2019). Media Pembelajaran Sejarah Era Teknologi Informasi. Syaharuddin, S., \& Mutiani, M. (2020). Strategi Pembelajaran IPS: Konsep dan Aplikasi.

Syaharuddin, S. (2020). Pembelajaran Masa Pandemi: Dari Konvensional Ke Daring. Pembelajaran Masa Pandemi: Dari Konvensional Ke Daring.

Syaharuddin, S. (2020). Menimbang Peran Teknologi dan Guru dalam Pembelajaran di Era COVID-19. Menimbang Peran Teknologi dan Guru dalam Pembelajaran di Era COVID-19.

Ulya, N. M. (2017). Pengaruh Metode Pembelajaran dan Tipe Kepribadian Terhadap Hasil Belajar Bahasa Arab (Studi Eksperimen Pada MAN 1 Semarang). Nadwa, 10(1), 125. 